\title{
RELATIONSHIP BETWEEN ORAL CONTRACEPTION AND THE RISK OF BREAST CANCER
}

\author{
Bening Rahimi Titisari'), Vitri Widyaningsih'², Bhisma Murti1) \\ 1)Masters Program in Public Health, Universitas Sebelas Maret \\ ${ }^{2)}$ Faculty of Medicine, Universitas Sebelas Maret
}

\begin{abstract}
Background: Oral contraceptive uptake has been linked to an increased risk of breast cancer in the current studies. A systematic review and meta-analysis was conducted to investigate the relationship between oral contraception and the risk of breast cancer.

Subjects and Method: A systematic review and meta analysis was conducted to assess the association between oral contraceptive and the risk of breast cancer. This study collecting articles published from Google Scholar, PubMed, and Sciencedirect electronic databases, from 2010 to 2021. The inclusion criteria were full text, case control study, and reporting adjusted odd ratio. The selected articles were analyzed using PRISMA guideline and quantitative data were assessed by Revman 5.3 application program.
\end{abstract}

Results: 7 case control studies involved 1,809 cases and 1,829 control study subjects. Oral contraception increased the risk of breast cancer 2.51 times $(\mathrm{aOR}=2.51 ; 95 \% \mathrm{CI}=$ 2.04 to 3.07 ; $\mathrm{p}<0.001$ ). No publication bias was found in this study.

Conclusion: This meta analysis provides evidence of oral contraceptive use increases risk of breast cancer.

Keywords: oral contraceptive, breast cancer, meta analysis

\section{Correspondence:}

Bening Rahimi Titisari. Masters Program in Public Health, Universitas Sebelas Maret. Jl. Ir. Sutami 36A Surakarta 57126, Central Java. Email: dr.beningbiru@gmail.com Mobile: 082194287848. 